\title{
Crkva sv. Martina u Svetom Lovreču Pazenatičlkom - privatna crkva porečkih biskupa ili istarskih (mark)grofova?
}

Izvorni znanstveni rad | Original scientific paper UDK 726.54.033.4(497.5-3 Istra)1 Primljeno: 17. I. 2011.

\begin{abstract}
Izvadak
U radu se donose nova razmišljanja o okolnostima izgradnje i izvornoj namjeni crkve sv. Martina u Svetom Lovreču Pazenatičkom, a povezano s time preispituju se dosadašnje spoznaje o povijesti samoga grada. Osim uvida u tipološka i morfološka obilježja arhitekture i njezina monumentalnog dekora te uvida u kulturno-povijesnu sliku poluotoka tijekom 11. stoljeća, daje se vrlo iscrpan pregled svih povijesnih dokumenata koji upućuju na ponovno promišljanje nekih općeprihvaćenih teza o povijesti Svetoga Lovreča te se iznose nove pretpostavke o mogućem naručitelju velike ranoromaničke crkve.
\end{abstract}

\section{Sintesi}

L'articolo propone delle nuove osservazioni sulle circostanze della costruzione e del proposito iniziale della chiesa di S. Martino di San Lorenzo del Pasenatico, il che comporta la revisione delle conoscenze finora acquisite sulla città stessa. Accanto all'analisi delle caratteristiche tipologiche e morfologiche dell'architettura e del suo decoro monumentale e accanto alla valutazione dell'aspetto storico-culturale della penisola nel XI secolo, viene presentata una vasta rassegna di tutti quei documenti storici che inducono a rivedere alcune tesi sulla storia di San Lorenzo comunemente accettate e di proporre nuove ipotesi sul potenziale committente della grande chiesa del primo romanico.

Ključne riječi: Sveti Lovreč Pazenatički, Istra, crkva sv. Martina, rana romanika, porečki biskup, istarski markgrof

Parole chiave: San Lorenzo del Pasenatico, Istria, chiesa di S. Martino, primo romanico, vescovo di Parenzo, margravio istriano 


\section{Župna crkva sv. Martina u Svetom Lovreču Pazenatičkom bez sumnje se} može smatrati jednim od najintrigantnijih istarskih srednjovjekovnih spomenika, ali i jednim od najznačajnijih ranoromaničkih spomenika na tlu čitave Hrvatske. Riječ je o monumentalnoj trobrodnoj, troapsidalnoj bazilici, najvećoj ranoromaničkoj crkvi u Hrvatskoj, ${ }^{1}$ u kojoj su, povrh toga, sačuvane iznimno vrijedne izvorne zidne slike (sl. 1a, b; sl. 3a, b). Po svojim tipološkim i morfološkim obilježjima crkva se uklapa u prevladavajuće trendove europske sakralne gradnje 11. stoljeća, a usporediva je ponajprije s brojnim primjerima ranoromaničke arhitekture na tlu sjeveroistočne Italije. ${ }^{2} \mathrm{U}$ tom je smislu prihvaćena njezina datacija u prvu polovinu, odnosno oko polovine 11. stoljeća. ${ }^{3}$ Takvu dataciju građevine potvrđuje i dodatno potkrepljuje analiza dekorativne arhitektonske plastike ${ }^{4}$ (sl. 2a-d, 4a-c) te također analiza zidnih

1 Prema ponovnim mjerenjima dimenzije crkve su 28,5x12 m (Damir Demonja, "Le chiese romaniche a tre navate in Istria”, Atti del Centro di ricerche storiche, XXIX, 1999., str. 152). Za pregled romaničke arhitekture u Istri vidi isti, Romaničke crkve u Istri, Zagreb 2007.; usp. sl. na str. 61-62; za pregled ranoromaničke arhitekture u Hrvatskoj vidi Miljenko Jurković, "Crkvena reforma i ranoromanička arhitektura na istočnom Jadranu”, Starohrvatska prosvjeta, III/20, 1990., str. 191-213; isti, "L'architecture du premier âge roman en Croatie" (dalje: "L'architecture”), Hortus artium medievalium, 6, 2000., str. 83-92.

2 Najiscrpniju analizu arhitekture, uz osvrt na zaključke ranijih istraživača, donosi Mario Mirabella Roberti ("La chiesa e le mura di San Lorenzo del Pasenatico" (dalje: "La chiesa"), Atti e memorie della Società istriana di archeologia e storia patria, XXVII-XXVIII, 1979.-1980., str. 63-86 [prethodno objavljeno u: Arte del primo millenio, Torino 1953., str. 91-110]). Prostornu koncepciju crkve, kao i niz drugih detalja (slijepi lukovi na vanjskom plaštu apsida građevine, okviri prozora [tranzena, op. a.], polustupovi prislonjeni uz ramena apside i zapadnu fasadu, lezene na začelju srednjega broda i dr.), povezuje s krugom ranoromaničke arhitekture na prostoru sjeveroistočne Italije (Katedrala u Akvileji, 1031.; Katedrala u Caorleu, 1038.; baptisterij u Concordiji, 11. st.; Katedrala u Trstu, 11. st.; Santa Fosca na Torcellu, početak 11. st. [dataciju R. Polacca prenosi Clementina Rizzardi, "Chiesa e impero nel medioevo: le abbazie di Ravenna e dell'area padanoadriatica fra tradizione e innovazione”, Hortus artium medievalium, 13/1, 2007., str. 132, bilj. 62]) i datira crkvu oko polovine 11. stoljeća (autor navodi i vrlo širok raspon datacija spomenika, od 4. do 11. stoljeća, koji su predlagali raniji istraživači). Na njegove se zaključke nadovezao niz kasnijih istraživača, koji su dodali još neke od komparativnih primjera arhitekture s prostora Veneta i Furlanije (Opatijska crkva u Pomposi [1026.]; San Niccolò na Lidu [polovina 11. st.] i niz crkava kasnijih razdoblja) te produbili zaključke Mirabelle Robertija, definirajući krug sjevernojadranskih investicija 11. stoljeća vrlo sličnih tipoloških i morfoloških karakteristika, koje su nastale u specifičnim povijesnim okolnostima. Laura Safred ("La cattedrale di San Giusto a Trieste: la fase architettonica altomedievale", Arte in Friuli, arte a Trieste, 5-6, 1982., str. 99-102) uključuje baziliku sv. Martina u Svetom Lovreču u krug investicija koje se nadovezuju na djelovanje akvilejskoga patrijarha Popona (1019. - 1042.), najjačeg oslonca carske vlasti u sjeveroistočnoj Italiji (Katedrala u Akvileji, Katedrala u Trstu, Katedrala u Caorleu, San Niccolò na Lidu, Santa Fosca na Torcellu), a koje podrazumijevaju obnovu ranokršćanske tipologije arhitekture te prihvaćanje oblika karakterističnih za okolicu Regensburga i Milana (tri istaknute apside); Giuseppe Bergamini i Sergio Tavano (Storia dell'arte nel Friuli-Venezia Giulia, Udine 1991., str. 176) dodaju neke od kasnijih primjera koji pripadaju istome kulturnom krugu i ponavljaju sličnu tipologiju (Santa Maria e Donato na Muranu, San Giovanni al Timavo i dr.).

3 Ivan Matejčić, "Jedna dvoapsidalna crkva: Sveta Marija Mala kod Bala”, Radanje prvog hrvatskog kulturnog pejsaža, ur. M. Jurković i T. Lukšić, Zagreb 1996., str. 236, bilj. 13 (autor ističe crkvu sv. Martina u Svetom Lovreču kao ključni spomenik ranoromaničke arhitekture u Istri, a na osnovi komparacija arhitektonske plastike datira ju u prvu polovinu ili oko polovine 11. st.); Jurković, "L'architecture", str. 84-86 (autor navodi crkvu kao rani spomenik reformatorskih ideja prve polovine 11. stoljeća). Vidi također Jean-Pierre Caillet Danielle Gaborit-Chopin - Éric Palazzo, L'Europe de l'an mil, ur. Pierre Riché, Zodiaque, 2001., str. 149-225.

Dataciju potvrđuju prozorske tranzene s pleternim ukrasom od učvorenih kružnica, koje se nalaze in situ u sjevernoj i južnoj apsidi te na južnom bočnom zidu građevine i kapiteli kolonada crkve. Za sistematizaciju arhitektonske plastike vidi Nikolina Maraković, Zidno slikarstvo u Istri od 11. do 13. stoljeća. Revalorizacija lokalne umjetničke baštine u europskom kontekstu (dalje: Zidno slikarstvo), doktorska disertacija, Zagreb 2009., str. $54-58$. 
slika sačuvanih u bočnim apsidama crkve (sl. 3a, b), koje se prema svojim stilskim karakteristikama u potpunosti uklapaju u korpus otonskoga i postotonskoga slikarstva južnonjemačkih i sjevernotalijanskih prostora. Na osnovi stilskih karakteristika lovrečke su zidne slike pripisane slikarima školovanim na prostoru onodobne Bavarske, moguće u okolici Salzburga (Seeon?), datirane su u drugu trećinu 11. stoljeća te su istaknute kao izrazito dragocjen primjer postotonskoga, odnosno ranoromaničkoga slikarstva u regiji. ${ }^{5}$ Kao i odavna poznate i blisko datirane zidne slike u crkvi sv. Mihovila u Kloštru nad Limom, ${ }^{6}$ one upućuju na veze istarskih prostora s južnonjemačkim samostanskim centrima.

Kontakti istarske crkve i južnonjemačkih samostana tijekom 11. stoljeća nalaze svoju potvrdu u pisanim povijesnim izvorima. Porečki je biskup Engilmar (Engilmarus $)^{7}$ održavao kontakte s benediktinskim samostanima u Regensburgu i Niederalteichu ${ }^{8}$ te je na tim prostorima dao izraditi poznati

5 Analiza zidnih slika pokazuje da je riječ o likovnom izričaju u kojemu se mogu prepoznati zanimljive stilske "nedosljednosti” i u kojem se na vrlo originalan način sažimaju stilske karakteristike koje su u starijim istraživanjima pokatkad bile percipirane kao međusobno isključive ("otonska”, odnosno "postotonska" slikarska tradicija i "bizantizirajuće” slikarstvo). Ove zidne slike omogućavaju problematiziranje pitanja "bizantiz(a)ma" u slikarstvu južnonjemačkih samostanskih škola te pitanja "(adrio)bizantizma” u zidnome slikarstvu sjevernojadranskoga prostora. Osim toga, njihova iznimna kvaliteta i dobra sačuvanost (ponajprije se ovdje misli na oslik južne apside bazilike) te također činjenica da spadaju među malobrojne primjere zidnoga slikarstva toga doba koje se može pripisati južnonjemačkom slikarskom krugu, doprinose njihovoj važnosti za daljnja proučavanja umjetnosti 11. stoljeća u Europi (vidi Nikolina Maraković, "Le pitture murali nella chiesa di San Martino a San Lorenzo del Pasenatico: nuove interpretazioni di un capolavoro pittorico di XI secolo in Istria" (dalje: "Le pitture murali"), Hortus artium medievalium, 16, 2010., str. 311-332; ista, "Zidne slike u crkvi sv. Martina u Svetom Lovreču (Istra): nove spoznaje na tragu Fučićevih opažanja” (dalje: "Zidne slike”), Zbornik Međunarodnog znanstvenog skupa o životu i djelu akademika Branka Fučića (1920. - 1999.) - „Az grišni diak Branko pridivkom Fučić“, Malinska, Dubašnica, otok Krk, 30. i 31. siječnja te 1. veljače 2009. [u tisku]).

6 Vidi Ana Deanović, "Ranoromaničke freske u opatiji svetog Mihovila nad Limskom Dragom” (dalje: "Ranoromaničke freske"), Bulletin Jugoslavenske akademije znanosti i umjetnosti, IV, 9-10, 1956., str. 12-20; Maraković, Zidno slikarstvo, str. 23-50.

7 Za pregled porečkih biskupa vidi Francesco Babudri, "I vescovi di Parenzo e la loro cronologia" (dalje: "I vescovi”), Atti e memorie della Società istriana di archeologia e storia patria, XXV, 1909., str. 170-284.

8 Prije nego je postao porečkim biskupom, Engilmar je bio redovnik u samostanu u Niederalteichu. Godine 1037. bio je ondje prisutan prilikom posvećenja nove samostanske crkve, a kao pripadnik kruga prijatelja samostanske zajednice sv. Emerama bio je čest gost u Regensburgu (vidi Florentine Mütherich - Karl Dachs [ur.], Regensburger Buchmalerei (von frühkarolingischer Zeit bis zum Ausgang des Mittelalters), katalog izložbe (16. 5. - 9. 8. 1987.), München 1987., str. 36, kat. 22, bibliografija). Podatak o smrti biskupa Engilmara 1030. godine, koji B. Fučić prenosi iz Kamaldoljanskih anala (Branko Fučić, Srednjorjekorno zidno slikarstvo u Istri (dalje: Srednjovjekovno zidno slikarstvo), doktorska disertacija, Rijeka-Ljubljana 1964., str. 105, bilj. 5) nije točan. Već je F. Babudri naveo podatak o biskupovoj smrti nakon 1040. godine (Babudri, "I vescovi", str. 214-215, 281). Nadalje, u Nekrologu samostana sv. Emerama u Regensburgu navodi se da je porečki biskup Engilmar bio pripadnik kruga prijatelja samostanske zajednice sv. Emerama (mora se pretpostaviti da je kao takav povremeno gostovao u Regensburgu) te da je u Regensburg donesena vijest o njegovoj smrti 1045. godine (Das Martyrolog-Nekrolog von St. Emmeram zu Regensburg [ur. E. Freise, D. Geuench, J. Wollasch], Monumenta Germaniae historica - Libri Memoriales et Necrologia N. S. 3, Hannover 1980., str. 77 (na digitalnoj bazi podataka Monumenta Germaniae historica [dalje: $M G H]$ - http://www.mgh.de/). 
Engilmarov benedikcional, ${ }^{9}$ a moglo bi se pretpostaviti da su kontakti postojali i u vrijeme njegovih nasljednika. ${ }^{10}$ Općenito je prisutnost njemačkoga plemstva u visokim crkvenim krugovima Svetog Rimskog Carstva postala ključna za vrhovnu vlast, odnosno za učinkovito upravljanje Carstvom. I otonski i salijski vladari uvelike su se oslanjali na kler te osobe bliske dvoru postavljali za biskupe i nadbiskupe po cijelome carstvu, osiguravajući tako bolju upravu nad golemim teritorijem. ${ }^{11}$ Najbolje to potkrepljuje podatak da su akvilejski patrijarsi, koji su, počevši od druge polovine 10. stoljeća, postali važni eksponenti carske politike, uglavnom bili vrlo bliski dvoru te da su do sredine 13. stoljeća gotovo svi bili njemačkoga podrijetla. ${ }^{12}$ Moguće je da je upravo u skladu s takvom politikom 1028. godine za porečkoga biskupa izabran redovnik njemačkoga podrijetla, Engilmar iz Niederalteicha. Kontakte između istarske crkve i južnonjemačkih samostana potvrđuje i nedavno objavljena studija o šibenskom Liber sequentiarum et sacramentarium. ${ }^{13}$ Hana Breko Kustura, naime, dokazuje da je spomenuti rukopis nastao oko 1050. godine u bavarskom skriptoriju Tegernsee te da je najvjerojatnije bio napravljen za crkvu sv. Tome u srednjovjekovnoj Puli. Prepoznavši ovaj rukopis kao primjer “takozvanog 'kulturnog transfera' jedne njemačke liturgijske tradicije na ovim prostorima”, autorica donosi važan dokaz da je Istra, poput

9 Za Benedikcional vidi Ernst Friedrich Bange, Eine bayerische Malerschule des 11. und 12. Jahrhunderts, München 1923., str. 55, 79, 138, T. 48; Regensburger Buchmalerei, T. 15, 102, kat. 22; Irmgard Seide, "Zur Rezeption ottonischer Buchmalerei in Italien im 11. und 12. Jahrhundert", Studien und Mittleilungen zur Geschichte des Benediktinerordens und seinr Zweige, 39, 1997., razbacano; Marino Baldini, "Benedikcional biskupa Englmara. Početak istarskog freskoslikarstva”, Istarska Danica 2004, Pazin 2003., str. 107-112; Maraković, Zidno slikarstvo, str. 41-43.

10 Za biskupe vidi Ferdinando Ughelli, Italiae Sacrae, Venezia 1717. - 1722., vol. V, str. 403-404; Babudri, "I vescovi”, str. 214-216, 281. Nije mi poznato jesu li intenzivne veze s njemačkim regijama održavali i biskupi Arpo (Arpus, Arvus, Arnus) (prije 1045. - 1050.), Orso (1050. - 1060.) i Adelmar (Alemarus, Adelmanus) (prije 1060. - 1075.), čija su imena također poznata iz dokumenata

11 Za tzv. "ottonisch-salischen Reichskirchensystem” vidi Gerd Althoff, Otto III, prev. Phyllis G. Jestice, Philadelphia 2004., str. 20-22 i bilj. 32.

12 Poppo (1019. - 1042.), Eberardus (1043. - 1048.), Gosobaldus (1049. - 1062.), Ravongerius (1063. - 1068.), Singifredus (1068. - 1077.), Henricus (1077. - 1084.), Fridericus (1084. - 1086.), Voldaricus (1086. - 1121.), Richardus/Gerardus (1122. - 1229.), Peregrinus (1131. - 1161.), Voldaricus (1161. - 1182.), Gotifredus (1183. 1194.), Peregrinus (1194. - 1204.), Valterus (1204. - 1218.), Bertoldus (1218. - 1251.) (vidi Ughelli, Italiae Sacrae, V, str. 48-92; Heinz Dopsch, "Origine e posizione sociale dei patriarchi di Aquileia nel tardo medioevo" [dalje: "Origine e posizione"], Aquileia e il suo patriarchato, Atti del Convegno Internazionale di Studio, Udine, 2123. 10. 1999., ur. S. Tavano, G. Bergamini, S. Cavazza, Pubblicazioni della Deputazione di storia patria per il Friuli 29, Udine 2000., str. 289-313). Samo Richardus/Gerardus (1122. - 1129.), Peregrinus I. (1131. - 1161.) i, moguće, Peregrinus II. (1194. - 1204.) pripadali su talijanskome plemstvu (str. 290, bilj. 8).

13 Vidi Hana Breko Kustura, "Najstariji sakramentar srednjovjekovne Istre iz 1050. godine u kontekstu europskih liturgijskih kodeksa", Zbornik Odsjeka za povijesne znanosti Zavoda za povijesne $i$ društvene znanosti Hrvatske akademije znanosti $i$ umjetnosti, 26, 2008. (2009.), str. 1-48. 
Akvileje, u to doba bila otvorena južnonjemačkim utjecajima. ${ }^{14}$

Iz svih je dosadašnjih istraživanja crkve sv. Martina u Svetom Lovreču, i same arhitekture, ali poglavito njezinog monumentalnog dekora, moguće izvesti zaključak da ona spada među najznačajnije spomenike ranoromaničkoga razdoblja na tlu današnje Hrvatske. Monumentalnost crkve te izrazita kvaliteta njezinih zidnih slika opravdavaju pretpostavku da se izgradnja i posveta crkve treba povezivati s pripadnicima najviših društvenih krugova, koji su po svemu sudeći održavali kontakte s južnonjemačkim područjima te bili dobro upoznati s novim praksama u koncipiranju i uređenju liturgijskoga prostora u južnim dijelovima Carstva. U tom se smislu, nadalje, logično nameću pitanja o mogućem naručitelju i kontekstu gradnje lovrečke crkve, koja su usko povezana s pitanjima njezine izvorne namjene i odabira mjesta za njezinu izgradnju. Namjera je u ovome radu pojasniti neka nova razmišljanja, uz kritički osvrt na dosadašnje spoznaje i pretpostavke. Bez pretenzija da se na ovome mjestu podastru konačni odgovori, ovim će se radom ipak dati nova i drugačija interpretacija spomenika, potkrijepljena povijesnim dokumentima, koja bi trebala poslužiti prije svega kao smjernica ili oslonac za neka buduća, sustavnija istraživanja.

Župna crkva sv. Martina danas se nalazi u središtu Svetog Lovreča Pazenatičkog, ali je poznato da izvorno nije bila smještena unutar zidina ranosrednjovjekovnoga kastruma. Naime, istraživanja Marija Mirabelle Robertija, provedena polovinom dvadesetoga stoljeća, pokazuju da je crkva bila izgrađena neposredno uza zidine, odnosno, prislonjena na njih svojom zapadnom fasadom (sl. 5). ${ }^{15}$ Prema lokalnoj predaji, u samome centru kastruma je postojala crkva, moguće samoga zaštitnika, sv. Lovre, ${ }^{16}$ što bi mogao biti jedan od razloga zašto su crkvu sv. Martina izgradili izvan gradskih zidina, tim više što je riječ o objektu doista pozamašnih dimenzija. ${ }^{17}$ Važnije je pitanje, međutim, zbog čega je fasada crkve bila prislonjena uza zid kastruma, jer je takvim položajem zanijekana uobičajena uloga i simboličko značenje zapadnoga, ulaznog pročelja u sakralno zdanje.

14 Mogli bi se pridodati i nešto kasniji podaci o feudalnim posjedima južnonjemačkih crkava na Istarskome poluotoku - područje oko Pirana i Novigrada darovao je kralj Henrik IV. godine 1062. freisinškome samostanu sv. Andrije (Bernardo Benussi, Nel Medio Evo, Pagine di storia istriana, Collana degli Atti 23, Rovigno-Trieste 2004. [pretisak iz 1897.], Cap. III, 2. 8, bilj. 74), a područje u okolici Kopra godine 1067. freisinškome biskupu (Die Urkunden Heinrichs IV - Diplomatum Regum et Imperatorum Germaniae VI, ur. D. Gladiss, MGH, Berlin 1931., 187, str. 243-244- http://www.mgh.de/).

15 Mirabella Roberti, “La chiesa”, str. 64, sl. 1.

16 Vidi isto, str. 86, bilj. 73.

17 Vidi gore. 
Najznačajniji nam se podatak, po svemu sudeći, otkriva u jednom mnogo kasnijem dokumentu, zapisu iz 1836. godine, u kojemu se spominje da se s druge strane zidina, nasuprot crkvi, nalazila gradska palača. Ona je te godine srušena pa je crkva 1838. godine dobila novu fasadu. ${ }^{18}$ Iako je prema istraživanjima Mirabelle Robertija crkvu i gradsku palaču dijelio zid kastruma (gradska je palača s južnim ulazom u crkvu mogla komunicirati kroz vrata u zidinama uz jugozapadni ugao crkve - sl. 5), ${ }^{19}$ autor navodi svjedočenje svoga suvremenika, prema kojemu se iz gradske palače prema crkvi nekada otvarao prozor. ${ }^{20} \mathrm{~S}$ obzirom na to da je ovakva vrsta komunikacije između crkve i sjedišta svjetovne vlasti inače tipična za mnogo ranija povijesna razdoblja, nameće se pretpostavka da je spomenuti odnos crkve i gradske palače nasljedovao neko mnogo ranije rješenje. Neobičan izvorni položaj velike lovrečke bazilike, odnosno, krajnje nesvakidašnji odabir lokacije za njezinu izgradnju, objašnjiv je činjenicom da je ona od početka trebala komunicirati s gradskom palačom, smještenom s druge strane gradskih zidina. Što bi to, u konačnici, trebalo govoriti o funkciji i okolnostima izgradnje monumentalne lovrečke crkve?

Dimenzije crkve te tipološka i morfološka obilježja arhitekture po svemu se uklapaju u korpus ranoromaničke sakralne gradnje 11. stoljeća i već su istraživače naveli na zaključak da je riječ o spomeniku reformskoga razdoblja. ${ }^{21} \mathrm{U}$ ranijim je istraživanjima, osim toga, bilo spomenuto da su crkvu možda uzdržavali benediktinci. ${ }^{22}$ Iako bi se takva pretpostavka mogla obrazložiti usporedbama s istarskim benediktinskim samostanima koji se smještaju u gradove ili u njihovu neposrednu okolicu, ${ }^{23}$ upitno je ima li osnove za pretpostavku da je lovrečka crkva sv. Martina bila crkva benediktinskoga samostana. Naime, spomenuti podatak da se iz gradske palače prema crkvi nekada otvarao prozor pokazuje da je funkcija crkve bila usko povezana s

18 Isto, str. 65, bilj. 6. Autor navodi obraćanje župnika Pietra Precalija Porečkoj biskupiji iz 1836. godine, u kojem spominje da se rušenjem Palače morala srušiti i fasada crkve: "sta per rovesciarsi l'intera sua facciata attirata dal cadente Palazzo alla quale essa sta attaccata...”.

19 Isto, str. 64-65, sl. 1, bilj. 7. I danas crkva ima južni ulaz ispred kojega je gradska loža.

20 Isto, str. 65 , bilj. 6.

21 Jurković, "L'architecture”, str. 84-86.

22 Igor Fisković, "Nova viđenja oko benediktinskog samostana na Limu”, Izdanja Hrvatskog arheološkog društva, 18, 1997., str. 241. Nadalje, pretpostavljeno je postojanje benediktinskoga samostana negdje u blizini Svetoga Lovreča. Citirajući Pietra Kandlera, Ivan Ostojić prenosi pretpostavku da je grad dobio ime prema istoimenom benediktinskom samostanu koji je navodno ondje nekada djelovao. U daljnjem tekstu navodi da su se prvotni posjedi samostana sv. Petronile kod Dvigrada sterali i na području Svetoga Lovreča. Ante Šonje spominje crkvu sv. Benedikta kod Svetoga Lovreča, u kojoj su pronađeni ulomci pletera i koju bi trebalo datirati u 10. stoljeće (sve u Ivan Ostojić, Benediktinci u Hrvatskoj i ostalim našim krajevima, sv. 3, Benediktinci u Panonskoj Hrvatskoj i Istri (dalje: Benediktincı), Split 1963.-1965., str. 104-105 [sl. 525], 129-130, 137).

23 Ostojić, Benediktinci, razbacano. 
gradskom vlašću. ${ }^{24}$ Moglo bi se očekivati, osim toga, da je za predstavnika vlasti postojao zaseban, povlašten prostor na zapadnom dijelu građevine, kao što je to bila česta praksa u ranosrednjovjekovnoj i ranoromaničkoj crkvenoj arhitekturi. Prema položaju crkve u odnosu na zidine kastruma te prema njezinim opisima prije rušenja zapadne fasade mogao bi se izvesti zaključak da je ona od vremena svoje izgradnje trebala funkcionirati prije svega kao privatna crkva lokalnoga predstavnika vlasti. ${ }^{25}$ Tko je, međutim, mogao biti taj moćni feudalac koji je dao izgraditi najmonumentalnije ranoromaničko sakralno zdanje na ovim prostorima te ga dao oplemeniti zidnim slikama koje su po svim svojim karakteristikama usporedive s najznačajnijim ostvarenjima otonskoga i postotonskoga slikarstva na prostoru Carstva?

Kao vlasnik Svetoga Lovreča od najranijih se istraživanja navodi porečki biskup, ${ }^{26}$ što se doista čini kao vrlo logična pretpostavka, iako, koliko mi je poznato, dosad nije bila potanko analizirana niti sustavno argumentirana. Ovom ćemo prilikom preispitati ima li uopće nepobitnih dokaza da je kastrum Sveti Lovreč tijekom 11. stoljeća bio u vlasništvu porečkoga biskupa, odnosno, može li se spomenuta općeprihvaćena pretpostavka potkrijepiti i potvr-

24. Benediktinski su samostani često bili usko povezani s vrhovnom svjetovnom vlašću, što se iskazivalo u obnovama i izgradnjama sakralnih građevina u dalmatinskim gradovima u razdoblju rane romanike. Crkva sv. Eufemije (sv. Benedikta) primjerice, koja je pripadala splitskim benediktinkama, nalazila se tik uza zidine ranosrednjovjekovnoga grada (odnosno zidine Dioklecijanove palače), a njezina se izgradnja, koja je povezana s crkvenom elitom (splitski nadbiskup Lovro) i kraljevskom vlašću (Petar Krešimir IV.) povezuje s prvom fazom ranoromaničke crkvene reforme. (Za samostan sv. Benedikta u Splitu vidi Igor Fisković, "Il re croato del bassorilievo protoromanico di Spalato", Hortus artium medievalium, 3, 1997., str. 179-209) Bliskost kraljevskoj vlasti jasno je očitovana i u slučaju ženskog benediktinskog samostana sv. Marije u Zadru, kao i mnogih drugih. Kralj Petar Krešimir IV. sudjeluje u osnivanju i obdaruje mnoge dalmatinske samostane tijekom reformskoga razdoblja, kao i mnogi drugi europski vladari. S njegovom ličnošću povezuju se samostani sv. Ivana Evanđelista u Biogradu, sv. Petra na Rabu, sv. Marije i sv. Krševana u Zadru, sv. Tome u Biogradu, sv. Benedikta i sv. Stjepana u Splitu (vidi Igor Fisković, Reljef kralja Petra Krešimira IV, Split 2002., str. 152-157, bilj. 66, 70; str. 180-183; za samostan sv. Marije u Zadru vidi također Nada Klaić - Ivo Petricioli, Prošlost Zadra. Zadar u srednjem vijeku do 1409, Zadar 1976., str. 249-253). Plemstvo je, uostalom, bilo jedan od najvažnijih promicatelja ranoromaničke crkvene reforme (za ulogu plemstva u crkvenim reformama vidi John Howe, "The Nobility's Reform of the Medieval Church", The American Historical Review, 93, 2, 1988., str. 317-339). S izgradnjom benediktinskog samostana sv. Mihovila u Kloštru iznad Lima, primjerice, povezuju se porečki biskup i svjetovna elita (za posvetu crkve i donaciju grofice Acike vidi Pietro Kandler, Codice diplomatico istriano (dalje: CDI), Trieste 1986. (http://www.scriniumadriae.it/) (Anno 1040,12 Maggio, Indizione X: spominje se da je crkva izgrađena u čast sv. Mariji Djevici i sv. Mihovilu [...ecclesiam ad honorem Dei et Sancte Marie Virginis beatque Michaelis archangeli a domno Iohanne abbate...] te da je porečki biskup Engilmar pozvan da posveti crkvu [...et a domino Engelmaro venerabili Parentino episcopo eadem invitante consecratam humilima devotione...]; Anno 1040, 15 Settembre). Vidi također Danilo Klen, "Neke misli i podaci o Sv. Mihovilu nad Limom” (dalje: "Neke misli”), Bulletin Jugoslavenske akademije znanosti $i$ umjetnosti, XI, 1-2, 1963., str. 11-12; Fučić, Srednjovjekovno zidno slikarstvo, str. 106; Deanović, "Ranoromaničke freske”, str. 18). Smatram, međutim, da se crkva sv. Martina u Svetom Lovreču ipak ne treba direktno povezivati s djelovanjem benediktinaca, što donekle potvrđuje i ikonografski program južne apside, kakav ne bi najbolje odgovarao ranoromaničkoj benediktinskoj crkvi (za tumačenje ikonografije vidi Maraković, "Le pitture murali”, str. 312317; ista, "Zidne slike"). Zasad ju stoga treba promatrati prvenstveno kao investiciju jednog moćnog feudalca, koja se i arhitektonskim konceptom i zidnom dekoracijom uklapa u suvremene europske umjetničke tokove.

25 Naravno, nije isključeno da je istovremeno ispunjavala funkciju nove župne crkve.

26 Mirabella Roberti, "La chiesa”, str. 82. Takvo je mišljenje preneseno i u Istarska enciklopedija, ur. M. Bertoša i R. Matijašić, Zagreb 2005., str. 769. 
diti povijesnim dokumentima ili nam pak pisani povijesni izvori daju razloge i opravdanje za njezino ponovno promišljanje, otvarajući prostor za nove interpretacije i za stvaranje drugačije slike o povijesti grada u razdoblju oko polovine 11. stoljeća.

Izgradnju samoga kastruma, ${ }^{27}$ uz koji je bila dograđena crkva sv. Martina, Mirabella Roberti datira u odnosu na dva povijesna dokumenta. Prvi je darovnica cara Otona II. iz 983. godine, kojom car na biskupovu molbu porečkoj crkvi potvrđuje brojne posjede. ${ }^{28} \mathrm{U}$ spomenutom dokumentu se Sveti Lovreč ne spominje među posjedima porečke crkve te stoga Mirabella Roberti uzima godinu 983. kao terminus post quem za izgradnju kastruma. Drugi je dokument iz prve polovine 11. stoljeća, u kojemu se navode donacije istarske grofice Acike samostanu sv. Mihovila nad Limom. ${ }^{29}$ Mirabella Roberti, naime, drži da se upravo u to vrijeme ukazala potreba za jakim utvrđenim središtem na tome prostoru, u blizini dvaju konkurentskih - kastruma Calisedo (Castrum Calixedi) i opatije sv. Mihovila nad Limom (s obzirom na to da su porečki biskupi bili u stalnom sukobu sa spomenutom opatijom) - te da je kastrum Sveti Lovreč trebao biti novo uporište porečke crkve. Nadalje, Mirabella Roberti smatra da se na položaju današnjega gradića vjerojatno nalazila samo antička vila te da lovrečki kastrum prema načinu gradnje nije mogao biti ranobizantskoga postanka. ${ }^{30}$ Međutim, pozicija kastruma u blizini jedne od najznačajnijih istarskih antičkih prometnica (Via Flavia), ${ }^{31}$ a onda i važna uloga grada u kasnijim razdobljima, ${ }^{32}$ navode na zaključak da je lokalitet imao nekakvu ulogu u prostornoj organiza-

27 O tome kako je kastrum dobio ime postoje samo pretpostavke. M. Mirabella Roberti navodi kako je moguće da je dobio ime prema crkvi koja je prethodila današnjoj crkvi na groblju, a I. Ostojić smatra da je mogao dobiti ime prema pretpostavljenom benediktinskom samostanu, smještenom negdje u blizini grada (Mirabella Roberti, "La chiesa", str. 86, bilj. 73; Ostojić, Benediktinci, str. 104-105 [sl. 525], 129-130).

28 Kandler, CDI, Anno 983, 2 Giugno, Indizione XI (Verona): ...Cujus dignis postulationibus aures Nostrae pietatis inclinati, praetaxatae Ecclesiae Praedia nominatim Montonam, Rosarium, Nigrignanum, Turrim, quae est super piscatione novae, et illam de Cervaria, et Castrum Pisinum, Medelanum, quod a Regibus, seu ab Ugone largitum est, et Rubinum quantum ad Episcopatum sive Parentinae Ecclesiae donatum est a Nostris Antecessoribus videlicet in loco, qui dicitur duo Castella, et Valles cum omnibus pertinentiis suis juste, et legaliter ad praedictum Episcopatum pertinentibus, nec non Villis, Terris, Campis, Vineis, Pratis, Aquis, Aquarumque decursibus, Piscationibus, Molendinis, Venationibus, Montibus, Planitiebus, Villis cum omnibus rebus mobilibus, et immobilibus quae dici, aut nominari possunt, seu in quocumque loco praenominatus Episcopatus Terram habet, per hoc nostrum praeceptum confirmamus eidem Episcopo Adam, suisque successoribus, et corroboramus... Vidi također Mirko Zjačić, "Posjedovni odnosi porečke crkve od VI do XVI stoljeća" (dalje: "Posjedovni odnosi"), Jadranski zbornik, VIII, 1973., str. 34.

29 Za donacije grofice Acike vidi Kandler, CDI, Anno 1040, 15. settembre. U novijim istraživanjima dovedene su u pitanje (Klen, "Neke misli"); također vidi Mirabella Roberti, "La chiesa", str. 82 i dalje.

30 Mirabella Roberti, isto, str. 85, bilj. 67.

31 Željko Miletić, "Roman Roads along the Eastern Adriatic Coast: State of Research", Les routes de l'Adriatique antique, géographie et économie - Putovi antičkog Jadrana, geografija i gospodarstvo, Radovi s okruglog stola održanog u Zadru od 18. do 22. rujna 2001., Bordeaux-Zadar 2006., str. 127, sl. 2. Odvojci antičkih cesta koje su vodile prema Svetom Lovreču mogu se vidjeti i na satelitskim snimkama poluotoka. Na ovom podatku zahvaljujem kolegi dr. sc. Tinu Turkoviću.

32 Grad je odabran za centar Pazenatika. 
ciji poluotoka i u kasnoantičkome i u ranosrednjovjekovnome razdoblju, a slično je mišljenje izrazio i Branko Marušić. Prema Marušiću, naime, riječ je o utvrđenom naselju kasnoantičkih korijena ${ }^{33}$ ili pak o utvrđenom naselju koje je podignuto u prvim stoljećima franačke vladavine. ${ }^{34}$ Ako je Marušićeva pretpostavka točna, dakle, ako je kastrum kasnoantičkoga ili ranosrednjovjekovnoga postanka, zanimljivo je da se ipak ne spominje u potvrdi povlastica porečkome biskupu iz 983. godine, tim više što je prema Luji Margetiću isprava u kasnijim razdobljima nadopunjavana spornim područjima nad kojima je Porečka biskupija nastojala dokazati svoje ovlasti. ${ }^{35}$ Niti u kraljevskoj ispravi iz 11. stoljeća, kojom se biskupu Adelmaru (Alemarus, Adelmanus) ponovno potvrđuju posjedi porečke crkve te se uglavnom ponavljaju lokaliteti navedeni u ispravi Otona II. iz 983. godine, ne spominje se Sveti Lovreč. ${ }^{36}$ Iako je isprava prema Margetiću krivotvorena, ${ }^{37}$ ona posve sigurno govori o interesima porečke crkve. Nijedna od navedenih isprava ne predstavlja popis svih biskupovih posjeda te ih stoga ne možemo uzeti kao čvrst dokaz da Sveti Lovreč u to doba nije bio u biskupovu posjedu. Treba, međutim, ipak konstatirati da u njima ne nalazimo niti potvrdu da je bilo suprotno.

Kada se u povijesnim dokumentima prvi put pojavljuje ime mjesta? Dosadašnji istraživači rijetko ističu da se Sveti Lovreč prvi put spominje u

33 Branko Marušić, "Neki problemi kasnoantičke i bizantske Istre u svjetlu arheoloških izvora”, Jadranski zbornik, IX, 1975., str. 344, 346, sl. 6.

34 Isti, "Materijalna kultura Istre od 9. do 12. stoljeća", Izdanja Hrvatskog arheološkog društva, 11/1, 1986. (1987.), str. 118-119, sl. 11.

35 Lujo Margetić, "Iz pazinske prošlosti (u povodu tisućljeća prvog spomena Pazina)", u: isti, Istra i Kvarner. Izbor studija, Rijeka 1996., str. 147-154 (prethodno objavljeno u: Istra, 21, 5, 1983., str. 80-90), str. 147-150.

36 Isprava se navodi pod različitim datumima, čak i izvan vremena Adelmarova biskupovanja: Kandler, CDI, Anno 1040, IV. Non. Martii (Verona): ...Cujus dignis postulationibus aures nostrae pietatis inclinantes, praetaxatae Ecclesiae nominative Montonam, Rosarium, Nigrignanum, Turrim, quae est super piscationem Nonae, et Cervariam et Medelanum, et Castrum Pisinum, et illud quod a nostris antecessoribus largitum est, videlicet Ruvinum, quantum ad Episcopatum Sanctae Parentinae Ecclesiae donatum est, scilicet in loco qui dicitur duo Castella, et Valles cum omnibus pertinentiis suis, et legaliter ad praedictum Episcopatum pertinentibus; nec non villis, terris, campis, vineis, pratis, aquis, aquarum decursibus, molendinis, piscationibus, venationibus, montibus, planitiebus, vallis, cum omnibus rebus mobilibus, et immobilibus, quae dici, vel nominari possunt, seu in quocunque loco praenominatus Episcopatus terram habet, per hoc nostrum praeceptum confirmamus eidem Episcopo Alemaro, suisque successoribus et corroboramus...; Anno 1060, IV. Non. Martii (Verona): ...Cujus dignis postulationibus aures nostrae pietatis inclinantes, praetaxatae Ecclesiae praedia nominata Montona, Rosarium, Nigrignanum, Turrim quae est supra piscatione Nonae, et Cervariam, et Medilanum, et Castrum Pisinum, et illud quod a nostris antecessoribus largitum est, videlicet Ruvinum, quantum ad Episcopatum S. Parentinae Ecclesiae donatum est, scilicet in loco qui dicitur duo Castella, et Valles cum omnibus pertinentiis, juste et legaliter ad praedictum Episcopatum pertinentibus, nee non villis, terris, casis, vineis, pratis, et aquis, aquarumque decursibus, molendinis, piscationibus, venationibus, montibus, planitiebus, vallibus cum omnibus rebus mobilibus, et immobilibus, quae dici vel nominari possunt in quocumque loco praenominatus Episcopatus terram habet, per hoc nostrum praeceptum confirmamus...; za 1077. godinu vidi Die Urkunden Heinrichs IV..., 290, str. 379-380 - na http://www.mgh.de/. Riječ je o navodnoj carskoj potvrdi darovnice Otona II. s kraja 10. stoljeća. Isprava se pripisuje kralju Henriku III. ili Henriku IV. (?) te sukladno tome datira u 1040. ili 1060. (?) godinu. Za dataciju isprave vidi Zjačić, "Posjedovni odnosi”, str. 34, bilj. 9. Prema L. Margetiću riječ je o krivotvorini (Margetić, "Iz pazinske prošlosti”, str. 149, bilj. 11).

37 Margetić, "Iz pazinske prošlosti”, str. 149, bilj. 11. 
Engilmarovoj darovnici iz 1030. godine, kao castrum Sancti Laurentii. ${ }^{38}$ Pulskom samostanu sv. Mihovila spomenuti biskup daruje porečki samostan sv. Kasijana i neke zemlje na koje polaže prava. Isprava opisuje gdje se nalazi posjed o kojemu je riječ, a Pazin i Sveti Lovreč spominju se samo neizravno. Drugim riječima, iako se spominje castrum Sancti Laurentii, izrijekom se ne kaže da on pripada porečkoj crkvi jer se dio teksta ...que sunt fiscalia predicte ecclesie nostre... ne odnosi na same kastrume (castrum Pisinum i castrum Sancti Laurentii). ${ }^{39}$ Iz ove se isprave, dakle, ne može zaključiti da je kastrum u to doba bio dio biskupskoga feuda.

Indikativni bi u ovome smislu mogli biti i neki od kasnijih dokumenata. Isprava kojom papa Aleksandar III. godine 1177. (1178.) porečkoj crkvi potvrđuje samostane i mjesne crkve s kapelama navodi i Ecclesiam S. Laurentii cum Ecclesiis suis, ${ }^{40}$ što neki istraživači smatraju pokazateljem da je Sveti Lovreč u to doba bio u posjedu porečke crkve. ${ }^{41}$ Međutim, ponovno čitanje ove isprave navodi nas i na ponovno promišljanje općeprihvaćenih tumačenja. Naime, kod navođenja crkava pojedinih mjesta u tekstu se uvijek koristi prepozicija de (...Ecclesiam S. Mariae de Turre cum Capellis suis, Ecclesiam de Nigrignano cum Capellis suis, Ecclesiam S. Mariae de Campo cum Capellis suis, Ecclesiam de Rosario cum Capellis suis, Ecclesiam de Montona cum Capellis suis itd.), dok ona u spomenutom slučaju izostaje, jednako kao u slučaju nekih drugih, očito važnih samostana i crkava uz koje nije navedeno ime mjesta (Monasterium S. Barbare; Ecclesiam S. Vincentii cum Capellis suis). Čini se stoga opravdanim zapitati je li u našemu slučaju zapravo riječ o izvjesnoj (papi i porečkome biskupu očito dobro poznatoj) crkvi sv. Lovre i njoj pripadajućim manjim crkvama, možda čak one za koju se pretpostavlja da je prethodila

38 Kandler, CDI, Anno 1030, 7 Agosto, Indizione XIII (Parenzo): ...Tradens tradidi cenobio sancti archangeli Michaelis, quod prope civitatem Polensem consistit cum advocatore meo Waltramo Joanni abbati omnibusque ejus successoribus monasterium sancti martyris Cassiani situm, et fundatum infra muros civitatis Parentine cum omnibus suis pertinentiis, scilicet cum domibus, vineis, ortis, pratis, ac cum omnibus finiis, que sunt in contrata montis Petrosi, scilicet intra viam Sclavam, per quam itur Pisinum Castrum et viam per quam itur ad castrum sancti Laurentii, que sunt fiscalia predicte ecclesie nostre, idest nobis medietatem censi, ac etiam cum omnibus pascuis tam animalium, quam porcorum, et cum silvis, et glandaticum earum, ac capulum, et omnibus redditibus, juris predicto monasterio pertinentibus.

39 Za pomoć u tumačenju ove isprave zahvaljujem prof. dr. sc. N. Budaku, prof. dr. sc. B. Kuntić-Makvić i dr. sc. M. Levaku.

40 Lokaliteti se ponavljaju u privilegiju pape Inocenta IV. iz 1248. g. Za obje isprave vidi Ughelli, Italiae Sacrae, V, str. 404-406. Za dataciju vidi Zjačić, "Posjedovni odnosi”, str. 35.

41 Mirabella Roberti, "La chiesa”, str. 81, bilj. 49. Zanemarujući spomenutu ispravu iz 1030., autor ističe tekst ove isprave kao dokaz da Sveti Lovreč već tada nosi današnje ime te da je u vlasništvu porečkoga biskupa. Isto je mišljenje izraženo u Istarska enciklopedija, str. 769, te u Giovanni Radossi, "Stemmi di capitani, rettori e famiglie notabili di S. Lorenzo del Pasenatico in Istria", Atti del Centro di ricerche storiche, XXI, 1991., str. 188, uz pogrešan navod da je to prvi spomen Svetoga Lovreča u povijesnim dokumentima. 
lovrečkome kastrumu te po kojoj je on morao i dobiti ime..$^{42}$ Nadalje, čak i ako ne prihvatimo ovakvo tumačenje, ostajući pri tome da se ime $S$. Laurentii odnosi na samo mjesto, treba primijetiti da se tekst Ecclesiam S. Laurentii cum Ecclesiis suis odnosi isključivo na crkve te da se spominje u dijelu teksta papinske isprave u kojemu se biskupu potvrđuju samostani i crkve, ne i svjetovna vlast nad mjestima. Nasuprot tome, u drugom dijelu teksta spominju se neka mjesta nad kojima je biskupu potvrđena svjetovna vlast (...Castrum Vrsariae cum omnibus appendentiis suis, Castrum Castellionis cum appenditiis suis omnibus...), a u tom dijelu teksta nema spomena kastruma Svetoga Lovreča. Kako je isprava izdana na biskupov zahtjev (...tuis justis postulationibus benigniter annuentes...), možemo pretpostaviti da bi biskup tražio potvrdu svjetovne vlasti i nad lovrečkim kaštelom - da ju je imao. Iz svega navedenog proizlazi da bi papinska isprava iz 1177. (1178.) godine mogla biti samo dokaz da u to doba Sveti Lovreč nije bio u biskupovu posjedu, a ne i obratno. ${ }^{43}$

U nizu dokumenata iz 12. i 13. stoljeća spominju se visoki dužnosnici ili uglednici Svetoga Lovreča, često kao svjedoci različitih dogovora ili sporova između najjačih istarskih feudalaca. Primjerice, u dvama dokumentima iz 1183. godine, koji nam otkrivaju neke aspekte feudalnih odnosa između porečkoga biskupa, kneza Menharda i njegove obitelji te nekih sitnijih feudalaca, ali i akvilejskog patrijarha, spominju se Catulus Magister Scholarum (de S. Laurentio) i Bernardo Gastaldione de S. Laurentio. ${ }^{44} \mathrm{U}$ oba su dokumenta navedeni isključivo kao svjedoci dokumentiranih događaja, ali se ne može tvrditi da svjedoče kao biskupovi vazali. ${ }^{45}$ Zanimljiv je podatak da je upravo u Svetom Lovreču istarski grof Adalbert 1186. godine rješavao spor između Adalburnovih nasljednika i gradske komune Svetoga Lovreča, ${ }^{46}$ što pokazuje da je on u to doba bio gradić s vlastitom komunalnom upravom, a dogadaj je zabilježen upravo u glavnoj gradskoj crkvi (Actum in Castro S. Laurentii in Ecclesia Majori). ${ }^{47}$

\footnotetext{
42 Za crkvu sv. Lovre vidi Ostojić, Benediktinci, str. 104-105 [sl. 525], 129-130, 137. Vidi gore.

43 U slučaju potvrde biskupove svjetovne vlasti moralo bi u ispravi pisati castrum S. Laurentii cum appenditiis suis ili nešto slično. Za pomoć u čitanju i razumijevanju ove isprave zahvaljujem kolegi dr. sc. M. Levaku.

44 Kandler, CDI, Anno 1183. (Archivio domestico dei Marchesi Polesini); Anno 1183, 12 Agosto, Indizione XII. Pisino.

45 Nije mi poznato je li njihov identitet bio razmatran u ranijim istraživanjima. Lovrečkoga gastalda, nadalje, spominju također isprave iz 1186., 1194. (?), 1203. (?), 1225. godine itd. (Kandler, CDI, Anno 1186, 24 Ottobre, Indizione IV. Castel S. Lorenzo (Venerius Castaldio); Anno 1194, 5 Ottobre (Mattheus Castaldus); Anno 1203, 4 Novembre, Indizione VI. Parenzo (Bernardus Gastaldio); Anno 1225, 27 Novembre, Indizione XIII. Parenzo (Mengosus Castaldio).

46 Kandler, CDI, Anno 1186, 24 Ottobre. Vidi niže.

47 Kandler, CDI, Anno 1186, 24 Ottobre, Indizione IV. Castel S. Lorenzo.
} 
Što nam o posjedovnim odnosima govore dokumenti iz 13. stoljeća? U dokumentu kojim akvilejski patrijarh početkom 13. stoljeća potvrđuje granice "Posjeda sv. Maura" i u dokumentu kojim se te granice utvrđuju 1225. godine spominje se da on seže do crkve sv. Margarete, koja se navodno nalazila negdje na teritoriju Svetoga Lovreča, ali se sam grad ne navodi kao dio posjeda porečke crkve. ${ }^{48}$ Jedan od najzanimljivijih podataka o Svetome Lovreču nalazimo prilikom razgraničavanja posjeda akvilejskog patrijarha i Goričkih grofova 1275. godine, jer se tom prilikom određuju i obaveze nekih gradskih komuna: građani Svetoga Lovreča dužni su na davanja akvilejskom patrijarhu (istarskome markgrofu) i Goričkim grofovima, koji upravljaju u Istri brojnim patrijarhovim posjedima, a u Svetom Lovreču imaju toranj (ili palaču) (Ma che questa resti libera sotto l'autorità del Monsignor Patriarcha, e la Communità deve provedere per diffesa d'essa torre con il castello del sig. Conte contribuendoli quanto di sopra....). ${ }^{49}$ Prema ovim bi se podacima trebalo zaključiti da su Gorički grofovi u to doba Svetim Lovrečom upravljali u ime markgrofa, koji je bio njegov vlasnik. U ispravi koja govori o markgrofovim, odnosno patrijarhovim pravima u Istri (datirana je 1208. godinom, ali ju P. Kandler datira u 1303. godinu), spominje se i Sveti

48 Kandler, CDI, Anno 1203, 4 Novembre, Indizione VI. Parenzo: ...proprietatis et territorii S.Mauri: Incipiendo a Muglono, veniendo a Manuchera recto tramite, et de Manuchera veniendo ad Diglanum, quod est S.Mariae de Campo, et de Diglano veniendo ad Rojam Presbyteri Albini, et inde veniendo ad montem Messium qui est desuper Monasterium S.Michaelis de sub Terra versus Orientem, et deinde veniendo juxta lacum Vissignani, et de dicto Lacu veniendo juxta Ponzanum, et de Ponzano veniendo recto tramite juxta Ecclesiam S.Margaritae Castri S.Laurentii, et deinde veniendo usque ad locum, qui dicitur Sablonere, et de dicto loco veniendo ad Montem Lezosum, et de dicto monte veniendo ad horam montis Castri Calisetti versus Occidentem, et deinde veniendo ad Ripam Paludis, etiam versus Occidentem, et deinde veniendo usque ad Campum Basilium, qui est S.Michaelis de Lemo... Dokument je vjerojatno pogrešno datiran. Vidi Zjačić, "Posjedovni odnosi”, str. 35, bilj. 16. Kandler, CDI, Anno 1225, 7 Novembre, Indizione XIII. Parenzo: ...quod omnes terrae arratoriae et Herbaticum et nemus a via sclavonica, quae vadit Pisinum, juxta Antignana, usque ad Lemum et usque ad terminum D. Elichae, quod est juxta Ecclesiam S.Margaritae Castri S.Laurentii, reddit dicto Episcopo quartas, excepto territorio S.Georgii quod reddit Artuico, qui habet a dicto Episcopo..

49 Kandler, CDI, Anno 1275, 5 Maggio: ...Communità di S.Lorenzo deve, e sia tenuta contribuire al sig. Conte di Pisino la decima de' grani, vino e agnelli, e il sig. Conte di questa deve corrispondere ogni quarta a questo clero, e la Communità sia obbligata tutte le medeme decime metter, e aver poste in Pisino appresso annualmente il giorno de' S.S.Apostoli Pietro e Paulo in Mese di Giugno deve contribuire al sig. Conte Marche cinque di pepe, all'incontro, ch'esso sig. Conte dal giorno d'oggi in avvenire non debba altro tenere sua gente in questa torre. Ma che questa resti libera sotto l'autorità del Monsignor Patriarcha, e la Communità deve provedere per diffesa d'essa torre con il castello del sig. Conte contribuendoli quanto di sopra, e quando poi non volesse contribuirgli, e come si disse puntualmente servire, o osservare, che in ogni tal evento, possa il sig. Conte un'altra volta rimandare sua gente, rimettere e mantenere in essa torre o castello con tutti li proventi. Et che questa torre con castello non debono lasciare in abbandono e imbaradare, ma che la Communità è tenuta sempre separarli, e in ottimo stato conservarli senza minimo danno, o sminuimento, conforme dall'antichità è provenuto, e così fù statuito, convenuto, e imposto il fine... Autor objašnjava i nadopunjava tekst: “...Un Guglielmo di Cividale figura, in altri documenti, Marchese dell'Istria per Patriarca Raimondo, appunto nel 1275, la carica era ad anno... Nell'atto di confinazione ove si parla di S.Lorenzo si pattuisce tra Conte Alberto, e Marchese Guglielmo, pel presidio di quel luogo, che sarebbe stato del Patriarca, nel quale il Conte aveva torre o palazzo, e le decime. Ora è certo che nel 1281 i veneziani ponevano in S.Lorenzo Podestà e Pasinatico; che nel 1279 il Conte che aveva preso S.Lorenzo, lo restituiva ai veneziani; che le questioni fra questi ed il Conte nel 1278 erano per S.Lorenzo; che nel 1278 i veneziani avevano costretto S.Lorenzo all'obbedienza; che nel 1277 si fece pace fra Patriarca e Conte, discordie nate come è verosimile nell'anno stesso od il precedente. L'atto non può essere posteriore al 1277”. Za pomoć u interpretaciji ovog teksta zahvaljujem kolegi dr. sc. M. Levaku. 
Lovreč. Kao i u nekim drugim istarskim mjestima, u Svetome Lovreču patrijarh postavlja gastalda koji ondje upravlja u njegovo ime (...Item in sancto Laurentio ponit Gastaldionem suum et exercet omnem jurisdictionem...). ${ }^{50}$ Da je Sveti Lovreč u to doba bio u biskupovu posjedu vjerojatno ipak ne bi bio spomenut u dokumentu koji navodi samo mjesta nad kojima markgrof ima određena prava (Ista sunt Jura Domini Patriarchae et Ecclesiae Aquilegensis in tota Istria videlicet...), kao što nije spomenut, primjerice, biskupski kastrum Vrsar. Činjenica jest da se 1294. godine Gabrijel Minio iz Venecije, potestat Svetoga Lovreča, spominje se kao vazal porečkoga biskupa. ${ }^{51}$ Ipak, zanimljivo je da u svojoj žalbi papi iz 1301. godine porečki biskup nabraja mnogo kaštela na koje polaže pravo, kao na drevne posjede porečke crkve, ali ne navodi Sveti Lovreč. ${ }^{52}$

Izostanak spomena lovrečkoga kastruma među posjedima porečke crkve do kraja 13. stoljeća te u biskupovoj žalbi papi iz 1301. godine, kao i ovdje izneseni zaključci o vlasništvu nad kaštelom 1275. godine, otvaraju prostor za relativiziranje općeprihvaćenog viđenja povijesti grada te potiču na ponovna promišljanja, što uključuje i pitanje pripadnosti grada tijekom 11. stoljeća. Je li moguće da grad u tom razdoblju nije bio posjed porečkoga biskupa već da je njime upravljao netko od pripadnika svjetovne elite? Daju li nam povijesne okolnosti oko polovine 11. stoljeća ikakvo uporište za pretpostavku da je grad u to doba bio u vlasništvu istarskih grofova, odnosno markgrofova, i koliko uopće znamo o najmoćnijim istarskim svjetovnim feudalcima?

50 Kandler, CDI, Anno 1208, Aquileja: ...Item in sancto Laurentio ponit Gastaldionem suum et exercet omnem jurisdictionem et condemnat omnes offendentes et condemnationes sunt ipsius domini Patriarche et imponit ibi collectas et recepit expensas cum tota comitiua sua cum uadit illuc et nuncii sui scilicet habent expensas. Item habent ibi omnes regalias et potest facere de terra, et hominibus sicut vult, sicut de terra hominibus suis, et habet multa alia iura minuta. Item in loco de Duobus Castellis ponit Gastaldionem suum qui exercet omnem jurisdictionem et condemnationes omnes offendentes et condemnationes sunt ipsius domini Patriarche et generaliter in omnibus facit et habet sicut in sancto Laurentio, ut supra, et multa alia iura minuta...

51 ...domino Gabrieli Minio de Venetijs, potestati castri Sancti Laurentij, uasallo domini Bonifacij, episcopi Parentini (vidi Zjačić, "Posjedovni odnosi", str. 45, bilj. 79). U prijepisu potvrdnice kralja Rudolfa I. iz 1291. godine (porečkoj crkvi se potvrđuju posjedi navedeni u carskom privilegiju iz 983. godine) koji se čuva u Kaptolskom arhivu u Poreču nadodan je Sanctus Laurentius (Sanctus Laurentius et cum castro Vrsarie; vidi Zjačić, "Posjedovni odnosi”, str. 35, 36, bilj. 22). Moguće je upravo biskup dao nadopisati ovaj posjed. Ipak, Sanctus Laurentius se ne spominje kao castrum, za razliku od Vrsara.

52 Kandler, CDI, Anno 1301: ...Notum Paternitati Vestrae facio, quod Civitas Parentina et totum Territorium, quod Cives possiderunt Parentini, et Castra: Rubinum, Montona, Pisinum, Medelanum, Rosarium, Nigrignanum, Turris Nova, Turris Veterana, et illa de Cervaria, et Ursariae Castrum, et praedictorum Locorum Jurisdictio, et pars duorum Castellorum, et Castri, quod dicitur Vallis, et Territorium quod dicitur S. Mauri, cujus corpus requiescit in Ecclesia Parentina: Quod Territorium extenditur ad decem miliaria in longum, et ad octo in latum; sunt praedicta omnia de proprietate Ecclesiae, et Episcopi Parentini, et ad ipsius Mensam expectant, secundum quod in Privilegiis Imperatorum, et Regum Romanorum, et aliis autenticis scripturis plenius continetur... Izvori iz druge polovine 13. stoljeća pokazuju odnose gradske samouprave i Mletačke Republike, koja je u to doba pojačano širila svoju vlast nad istarskim gradovima (vidi Giovanni De Vergottini, Lineamenti storici della costituzione politica dell'Istria durante il medioevo (dalje: Lineamenti storici), Trieste 1974., str. 112, 118, 124; Kandler, CDI, 22. gennaro 1286, itd.). Godine 1271. Sveti Lovreč se predao mletačkoj vlasti, a 1304. godine Venecija je osnovala zapovjedništvo seoskoga područja za cijeli mletački dio Istre na čelu s kapetanom i sa sjedištem u Svetom Lovreču (Istarska enciklopedija, str. 769). 
Upravo je obližnji kastrum Calisedo (Castrum Calixedi, današnja Gradina) bio središte vlastelinstva istarskoga grofa Vecelina i njegove kćeri Acike. ${ }^{53}$ Grof Vecelin upravljao je Istrom od tridesetih godina 11. stoljeća, a Istra, po svemu sudeći, tada još uvijek nije funkcionirala kao posve samostalna pokrajina. Vecelinovom se kćeri Acikom oženio Popon I. (III.) od Weimara te je tim brakom Istru dobila ova plemićka porodica. ${ }^{54}$ Osobito važan dogadaj u istarskoj povijesti bilo je njezino osamostaljenje od Koruške, a pretpostavlja se da se to dogodilo nakon 1040. godine, upravo u doba vladavine Henrika III. (1039.-1056.) - kako bi smanjio ovlasti koruških vojvoda on je osamostalio Istru kao markgrofoviju, ovisnu direktno o centralnoj vlasti, kojom je upravljao markgrof. Bio je to ili Popon ili njegov stariji sin Ulrik I. iz kuće Weimar-Orlamünde. ${ }^{55}$ Kao terminus ante quem za osamostaljenje Istre u samostalnu markgrofoviju mogu se uzeti dokumenti iz šezdesetih godina 11. stoljeća, u kojima se Istra spominje kao Marchia Hystriae, odnosno marcha Histria, ${ }^{56}$ te u kojima se Ulrik I. spominje kao istarski markgrof. ${ }^{57}$ Ulrika I., koji je preuzeo vlast oko 1050. godine, ${ }^{58}$ neki povjesničari povezuju i s najstarijim istarskim dokumentom koji pokazuje ustrojstvo feudalne vlasti u samostalnoj Istarskoj markgrofoviji ("Istarska pax", koji se obično datira u vrijeme između 1040. i 1070.)..$^{59}$

53 Lokalitet se nalazi sjeverno od Limskoga kanala, sjeverno od Kloštra i jugozapadno od Svetog Lovreča. Kao središte feuda istarskoga grofa spominje se 1040. godine (vidi Istarska enciklopedija, str. 277).

54 Grof Vecelin i njegova žena Vilpurga nisu imali muške nasljednike pa je udajom njihove kćeri Acike za Popona I. Istra prešla u ruke kuće Weimar-Orlamünde.

55 U Istarska enciklopedija, str. 896, navodi se da je riječ o Poponu.

56 U kraljevskoj ispravi iz 1039. (1040.?) godine Istra se spominje kao provincija Carstva (...imperatoribus per totam Istrie provintiam...) (vidi u Die Urkunden Heinrichs III - Diplomatum Regum et Imperatoru Germaniae, V, MGH, ur. H. Bresslau, Berlin 1931., 12, str. 14-15; Kandler, CDI, Anno 1040, III Kal. Januarii, Indictione VIII, Ratisbone). U dokumentu iz 1060. godine i dokumentu iz 1062. godine spominje se kao Marchia Hystriae, odnosno marcha Histria, a spominje se i markgrof Ulrik (...Forma Sacramenti D(omini) W(odorlici) Marchionis...; ...in marcha Histria et in comitatu marchionis Odalrici...) (vidi u Kandler, CDI, Anno 1060; Die Urkunden Heinrichs IV - Diplomatum Regum et Imperatorum Germaniae, VI, ur. D. Gladiss, MGH, Berlin 1931, 93, str. $121-122$ [http://www.mgh.de/]). Za detaljan kronološki pregled naziva Istre vidi Benussi, Nel Medio Evo, Cap. III, 3. $3-12$.

57 Ulrik I. spominje se kao istarski markgrof 1060., 1062. (vidi gore) te ponovno 1064., u dokumentu kojim mu car Henrik IV. dodjeljuje posjede u Istri (Die Urkunden Heinrichs IV, 135, str. 176-177 [http://www.mgh.de/]): ...in pago Histrie in villis et castellis subternominatis: Puuiendi, Lompaga, Bangul, Curtalla, Lahaneuuit et in villa que vocatur ad sanctum Martinum, Ruz, Winstrum, Rana in comitatu Odalrici marchionis sitos eidem prefato Odalrico marchioni ob fidele servitium eius cum omnibus appendiciis... Ovdje treba napomenuti da se i u mnogo ranijim dokumentima Istra spominje kao marka. Početkom 10. stoljeća Istrom je upravljao grof Albuin, podređen kralju Berengaru, a u pismu koje se datira oko 907. godine navodi se: ... ut toliat Albuino / comiti/ ipsam marcham /Istriae/... 933. godine spominje se gospodar Istre kao Uuintherius Marchio (vidi Benussi, Nel Medio Evo, Cap. I, 4. 4, bilj. 144-145; Kandler, CDI, Anno 933, 12 Marzo, Indizione VI, Rivoalto). Ipak, 952. godine Istra je bila pripojena Bavarskoj zajedno s Veronsko-akvilejskom markom, što pokazuje da nije imala potpunu samostalnost u odnosu na druge pokrajine (vidi Benussi, Nel Medio Evo, Cap. I, 4. 15, bilj. 174; Cap. III, 1. 5).

58 Vidi u Istarska enciklopedia, str. 896.

59 Za različite prijedloge datacije vidi De Vergottini, Lineamenti storici, str. 29-30, bilj. 7. Za drugačiju interpretaciju ovog dokumenta vidi Lujo Margetić, "La »pace provinciale« tra gli Istriani e il Margravio W.", Atti del Centro di ricerche storiche, XV, 1984.-1985., str. 49-60 i isti, "Isprava o zemaljskom miru između istarskog stanovništva i markgrofa W.”, u: isti, Istra i Kvarner. Izbor studija, 213-230. 
Weimarski markgrofovi bili su vjerni carevi vazali (bili su i u rodu s carem Henrikom IV.), a uz to bili su i carevi saveznici u borbi za investituru. Istarski markgrof Ulrik I. napao je na sjeverozapadne granice hrvatskoga teritorija u doba vladavine Petra Krešimira IV. (događaj se datira između 1063. i 1070.), a (istarski markgrof?) Vecelin II., koji je u sukobu cara Henrika IV. i pape Grgura VII. ostao vjeran carev saveznik, ${ }^{60}$ kasnije se sukobio s hrvatskim kraljem Zvonimirom, vazalom pape Grgura VII. Poznato je također da je Vecelin sedamdesetih godina 11. stoljeća (oko 1076.) pružio utočište svrgnutome ugarskom kralju Salomonu (također carevu vazalu) u samostanu sv. Mihovila u Puli. Salomon je okončao život u Istri te je pokopan u pulskoj crkvi sv. Klementa, navodnome opatijskom mauzoleju istarskih markgrofova. ${ }^{61}$ Po svemu sudeći, upravo su se na granicama Istre i Dalmacije odigravali sukobi carevih i papinskih saveznika i upravo su se na toj granici štitili interesi međusobno sukobljenih strana u jeku papinske reforme i borbe za investituru. ${ }^{62}$ Svi ovi podaci govore o značaju i moći istarskih markgrofova te o dobrim odnosima sa samom carskom Krunom.

Crkva sv. Martina u Svetom Lovreču Pazenatičkom najveća je ranoromanička građevina na čitavom prostoru istočnojadranskoga priobalja te stoga opravdava pretpostavku da ju je izgradio jedan od najmoćnijih istarskih feudalaca 11. stoljeća. Nadalje, vrhunske zidne slike upućuju na činjenicu da je njihov naručitelj morao kontaktirati s južnonjemačkim središtima ili čak boraviti na području onodobne Bavarske. Istarski su grofovi, odnosno markgrofovi, iz porodice Weimar-Orlamünde (weimarski [mark]grofovi Popon I., Ulrik I. i Vecelin II.), među ostalim, naslijedili neke posjede na tome prostoru

60 Vidi Marija Mogorović Crljenko, "Istarski markgrofovi iz obitelji Weimar-Orlamünde u konstelaciji odnosa Carstva i papinstva u doba borbe za investituru”, Godišnjak Njemačke narodnosne zajednice - VDG Jahrbuch, 10, 2003., str. 85-86, bilj. 23, 24; Istarska enciklopedija, str. 896.

61 Istarska enciklopedija, str. 712.

62 Vidi Mogorović Crljenko, "Istarski markgrofovi”, razbacano; Robert Matijašić, "Od iskona do prevlasti Serenissime”, u: Pula. Tri tisućljeća mita i stvarnosti, Pula 2005., str. 42. 
te su se smatrali naturaliziranim Bavarcima. ${ }^{63}$ Međutim, prema povijesnim izvorima, može se zaključiti da su markgrofovi iz kuće Weimar-Orlamünde (Popon I. [muž grofice Acike i istarski grof], Ulrik I., ${ }^{64}$ Vecelin II.) boravili u Istri, a da je umjesto Ulrika I., u vrijeme njegova izbivanja, Istrom upravljao namjesnik (nuntius marchionis). ${ }^{65}$ Razdoblje oko polovine 11. stoljeća očito je po mnogočemu bilo ključno u povijesti istarskoga poluotoka. Sam status Istre, koja je, pretpostavlja se, upravo polovinom 11. stoljeća postala markgrofovija, ovisna direktno o caru, te prisutnost njemačkoga plemstva u ulozi jakog feudalnog gospodara, opravdavaju pretpostavku o njezinom kulturnom procvatu u to doba. Bilo bi, osim toga, očekivano da su ti moćni svjetovni feudalci u Istri ostavili neku monumentalnu investiciju, a crkva sv. Martina u Svetom Lovreču Pazenatičkom po svim bi svojim karakteristikama takvu pretpostavku doista mogla i opravdati.

Velika lovrečka bazilika izazivala je interes i divljenje već kod najranijih istraživača, a sam ju je Kandler opisao kao "baziliku stariju i savršeniju od one porečke" (sic). ${ }^{66} \mathrm{O}$ vrijednosti njezinih zidnih slika već smo više puta govorili i pisali. ${ }^{67}$ Cilj je ovoga puta bio prije svega pokušati dokučiti okolnosti izgradnje i značaj ove impresivne, nekoć raskošno opremljene crkve, koja se ubraja među najznačajnije srednjovjekovne spomenike u Istri - objasniti njezinu neobičnu lokaciju, a povezano s time i njezinu funkciju, te u skladu s već iznesenim tezama o vremenu njezine izgradnje iznijeti pretpostavku o njezinom mogućem naručitelju. Na ova se posljednja pitanja nužno nadovezao i jedan, za povjesničara umjetnosti, mnogo veći izazov - preispitati općeprihvaćene teze o povijesti samoga grada te iznijeti vlastita razmišljanja o njegovoj pripadnosti i njegovome značaju u proučavanome razdoblju.

63 Iako turinškoga podrijetla, obitelj Weimar-Orlamünde bila je u vazalnom odnosu prema bavarskome vojvodi jer je u Bavarskoj naslijedila neke posjede od obitelji Sempt-Ebersberg. Obitelj je naslijedila posjede od Adalberta i Eberarda Sempt-Ebersberg (vidi Benussi, Nel Medio Evo, Cap. III, 5. 14), a iz dokumenata se može iščitati da su se smatrali naturaliziranim Bavarcima (...Nos Woldaricus... ex natione nostra lege vivere baioariorum... - vidi u Kandler, CDI, Anno 1102, 16 Novembre, Indizione X. Aquileia). I kasniji markgrofovi, akvilejski patrijarsi Sigehard [Sigehardus, Singifredus] i Henrik iz Constanza) mogu se povezati s područjem Bavarske. Patrijarh Sigehard održavao je veze sa salzburškim nadbiskupom Gebhardom te zajedno s njime 1072. godine posvetio novoobnovljeni samostan Michaelbeuern, sjeverno od Salzburga, kao obiteljsku zadužbinu (vidi Heinz Dopsch, "Salzburg und Aquileia", u: Il Friuli dagli Ottoni agli Hohenstaufen, Udine 1983., str. 509-545., str. 524; isti, “Origine e posizione”, str. 293). Patrijarh Henrik von Biburg bio je iz roda bavarskoga plemstva (isti, "Origine e posizione”, str. 295). Međutim, stilska obilježja lovrečkih fresaka govore o tome da bi ih se trebalo datirati prije vremena ove dvojice akvilejskih patrijarha.

64 Postoje različita mišljenja o tome je li Istra osamostaljena u markgrofoviju za Popona I. ili Ulrika I. Vidi gore.

65 Ivo Goldstein, Hrvatski rani srednji vijek, Zagreb 1995., str. 345. Za funkciju i titulu vidi Benussi, Nel Medio Evo, Cap. III, 6, 5-7.

66 Kandlerove riječi prenosi Thomas Graham Jackson opisujući svoj dolazak u Sveti Lovreč upravo da bi vidio crkvu (Dalmatia, the Quarnero and Istria, vol. III, Oxford 1887., str. 333-334). Kandler je pretpostavljao je crkva izgrađena u 4. stoljeću.

67 Vidi gore. 
Povijesni dokumenti u kojima se spominje Sveti Lovreč pružaju nam ponekad vrlo kontradiktorne informacije. Čini se, ipak, da pretpostavku prijašnjih istraživača da je castrum Sancti Laurentii sagrađen kao uporište porečkoga biskupa krajem 10. ili tijekom prve polovine 11. stoljeća, što bi značilo i to da je on naručitelj lovrečke bazilike, navedeni povijesni podaci ne potvrđuju. Nažalost, nemamo niti pisanih dokumenata koji bi izravno potvrdili da je Sveti Lovreč u tom razdoblju bio dio carskoga posjeda ili pak da je bio u feudu istarskoga grofa ili markgrofa. ${ }^{68}$ Indikativni su, ipak, svi dokumenti u kojima se kastrum Sveti Lovreč ne navodi među posjedima na koje je porečka crkva tradicionalno polagala prava, ${ }^{69}$ tim više što ranoromanička crkva sv. Martina vrlo rječito govori o njegovome značenju tijekom 11. stoljeća. Iz sačuvanih dokumenata doznajemo jedino da je kaštel krajem 13. stoljeća bio uključen među posjede porečke crkve, dok u dosadašnjim istraživanjima nisu bili istaknuti oni povijesni podaci koji navode na zaključak da je vlasništvo nad njim do kraja 13. stoljeća imao neki drugi istarski feudalac. Naposljetku nam preostaje barem postaviti pitanje: je li moguće da je castrum Sancti Laurentii ostao izvan posjeda koji su potkraj 10. stoljeća potvrđeni kao feud porečkoga biskupa te da je njime tijekom 11. stoljeća upravljao upravo netko od najviših pripadnika svjetovne elite, a kao jedan od simboličkih pokazatelja svojih ovlasti i svoje moći sagradio reprezentativnu crkvu koja se po svojoj raskoši trebala mjeriti s najznačajnijim sakralnim zdanjima istarskih priobalnih gradova? ${ }^{70}$ Čitav ovdje izneseni slijed razmišljanja ponudio je, nažalost, mnogo više pitanja nego konačnih odgovora. Ipak, predočena bi rasprava trebala barem poslužiti kao izazov i poticaj za daljnja promišljanja te otvoriti prostor za neka buduća istraživanja.

* Zahvaljujem kolegi dr. sc. Mauriziju Levaku na diskusijama tijekom kojih su se iskristalizirali neki od važnih zaključaka izloženih u tekstu.

68 O posjedima za koje se navodi da su darovani istarskome markgrofu (1064.) vidi gore.

69 Osobito dokumenti iz 1040/60., 1177. te iz 1301. godine. Vidi gore.

70 Ova je teza prvi put iznesena u Maraković, Zidno slikarstvo, str. 95-102. 


\section{Ilustracije}
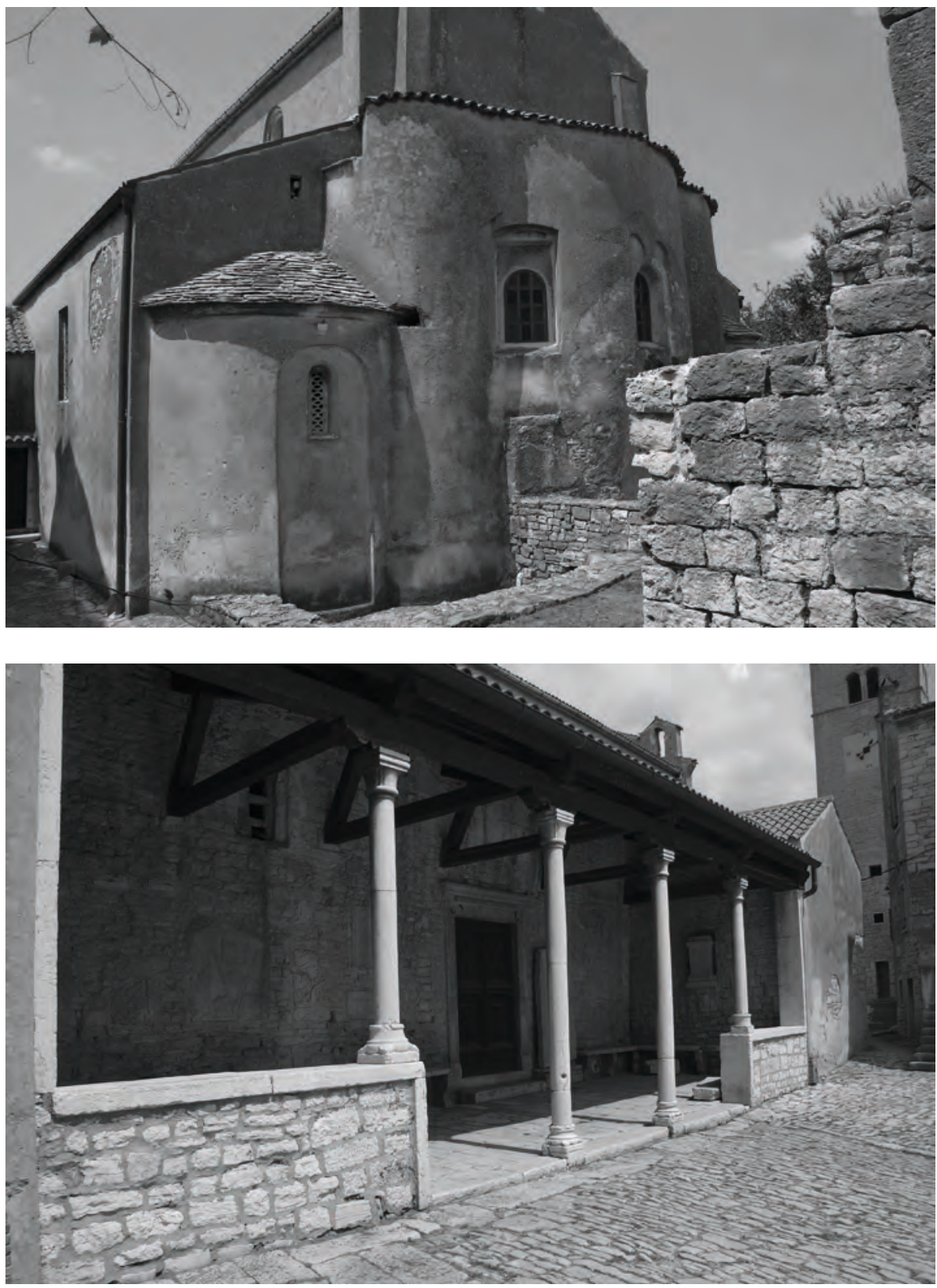

Sl. 1 - a. Crkva sv. Martina u Svetom Lovreču, začelje; b. Crkva sv. Martina u Svetom Lovreču, južno pročelje s gradskom ložom 

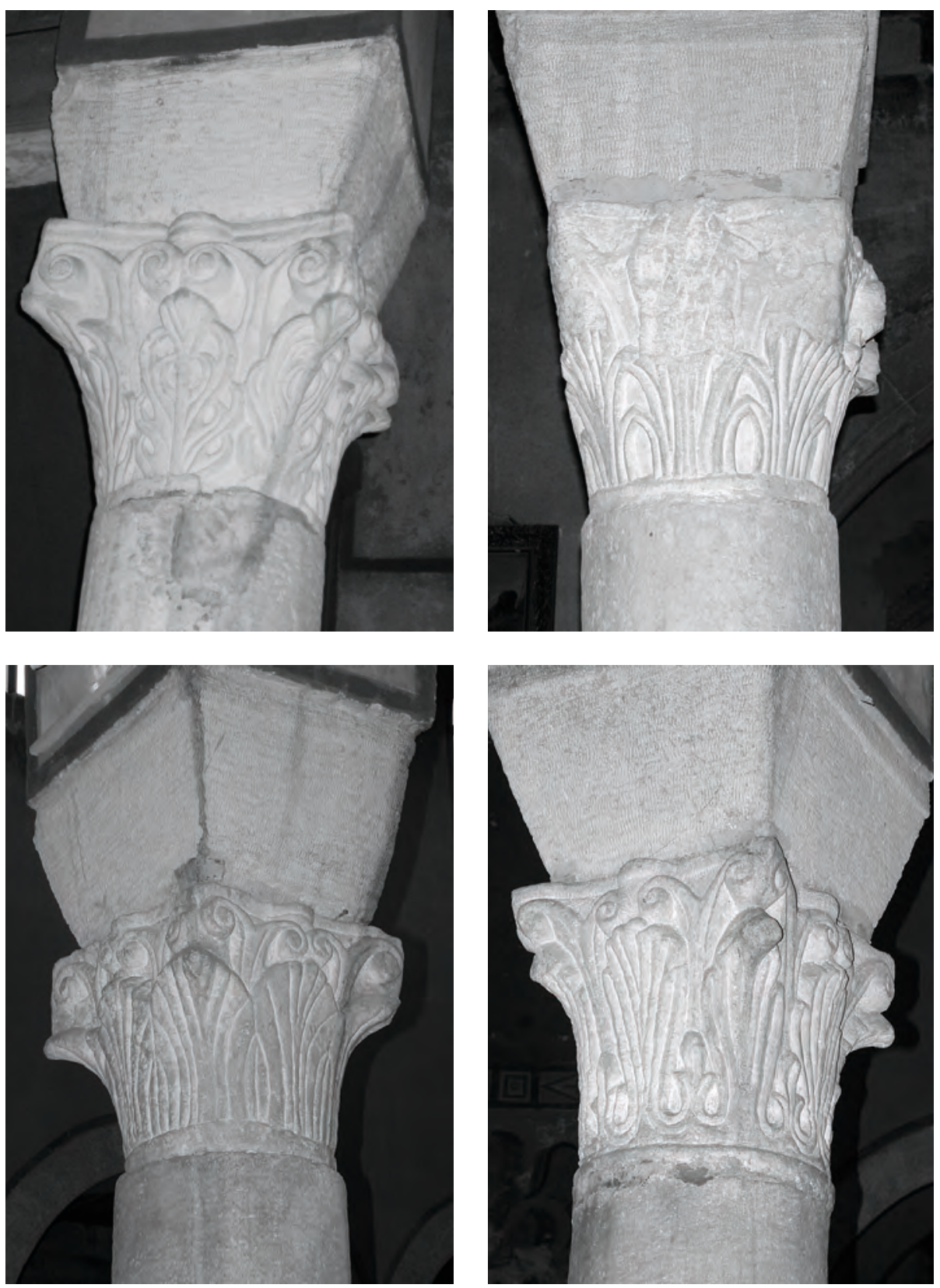

Sl. 2 - a-c. Crkva sv. Martina u Svetom Lovreču, različiti tipovi kapitela kolonade 

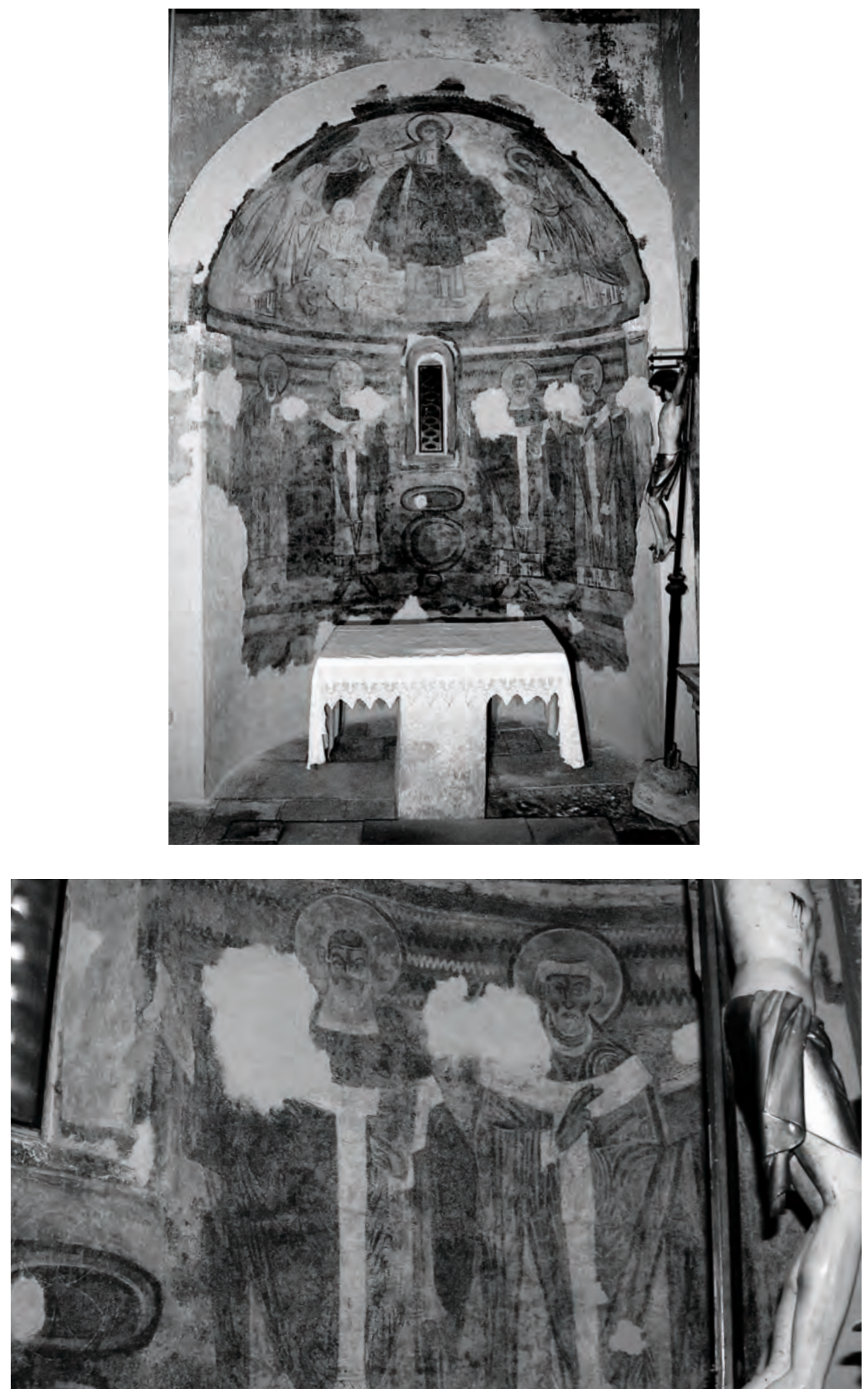

Sl. 3 - a, b. Crkva sv. Martina u Svetom Lovreču, zidne slike u južnoj apsidi 

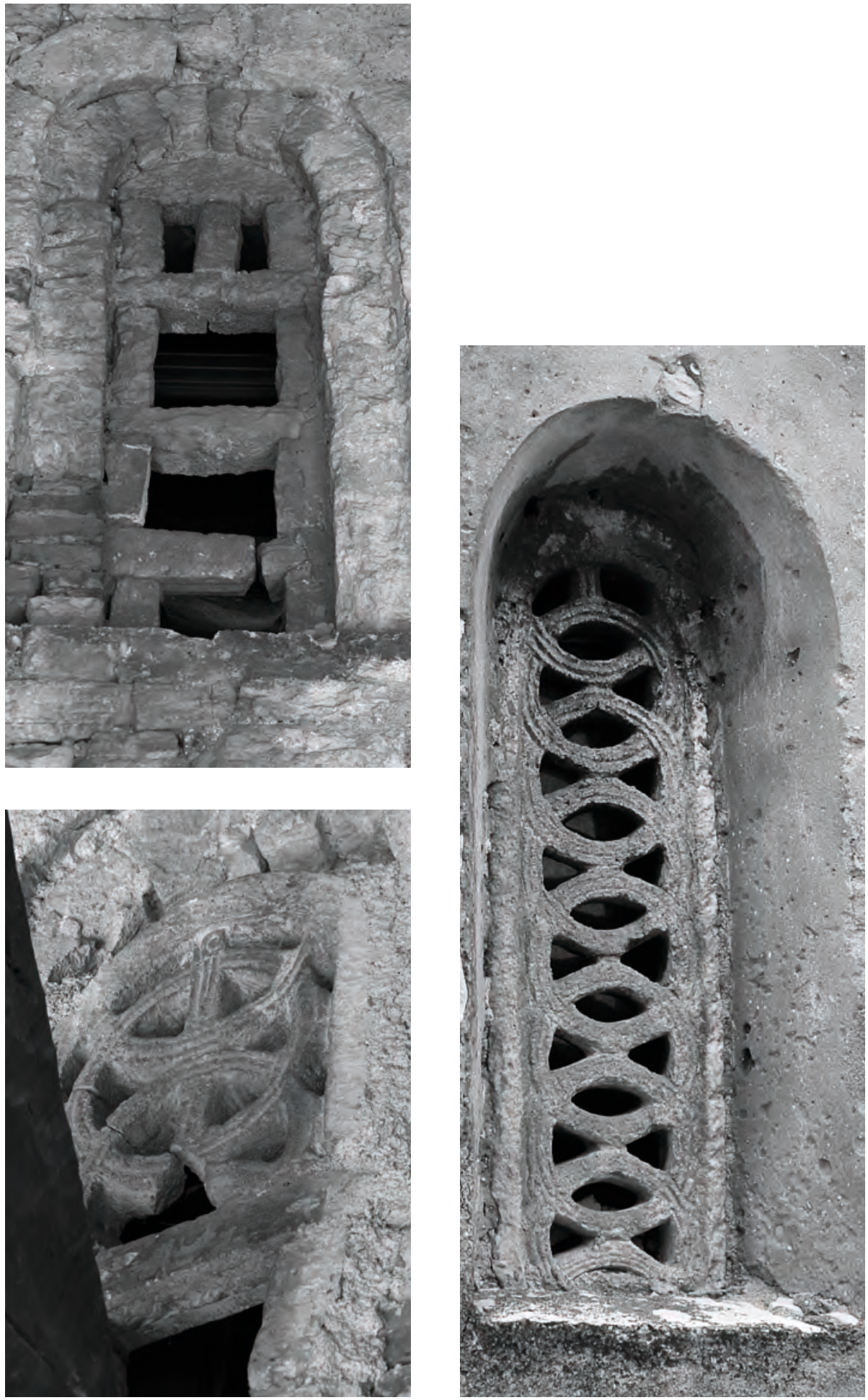

Sl. 4-a, b. Crkva sv. Martina u Svetom Lovreču, prozorske tranzene na južnom zidu crkve (a,b) i južnoj apsidi (c) 


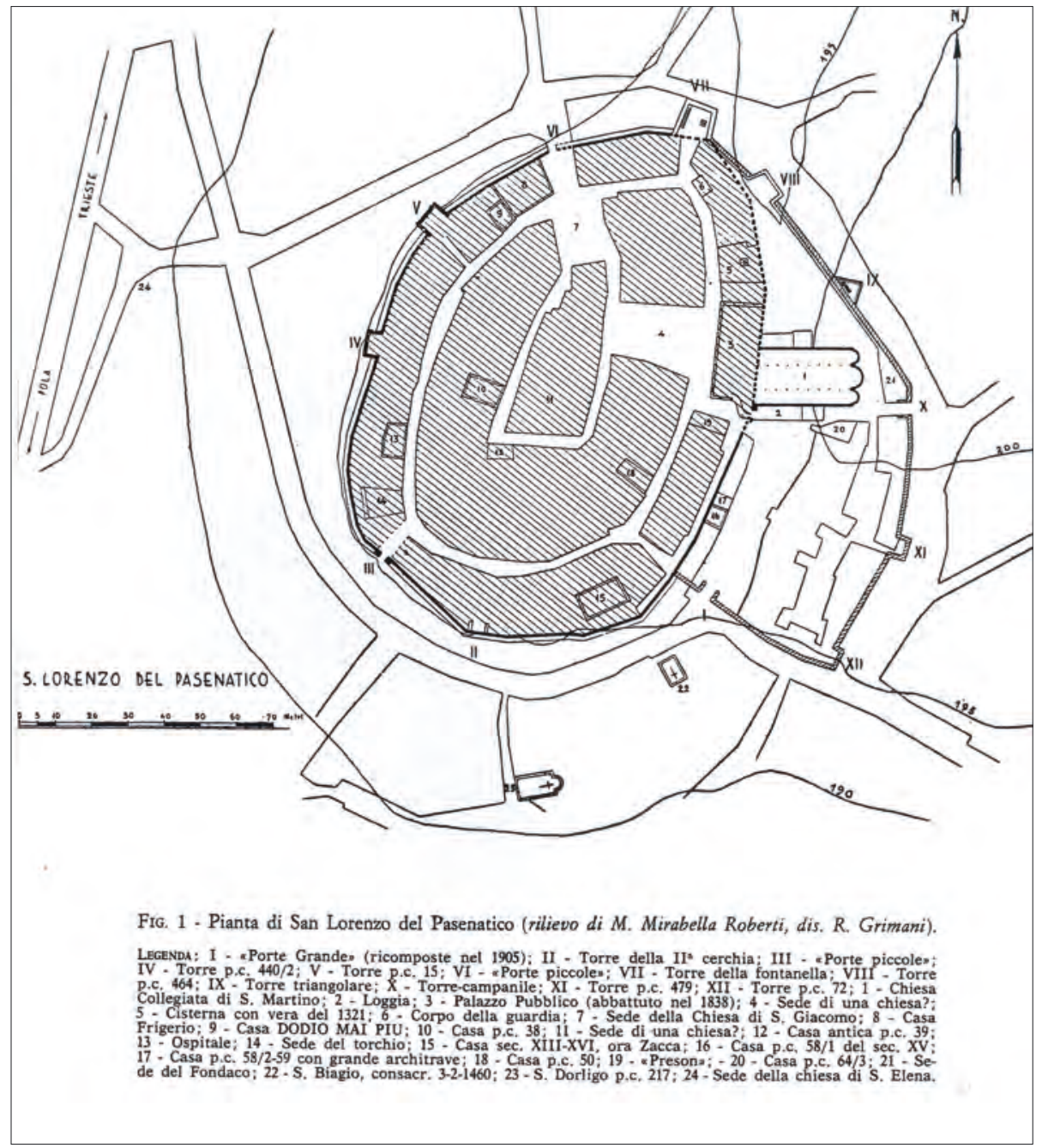

Sl. 5 - Sveti Lovreč Pazenatički, tlocrt (preuzeto iz M. Mirabella Roberti, "La chiesa e le mura di San Lorenzo del Pasenatico", Atti e memorie della Società istriana di archeologia e storia patria, XXVII-XXVIII, 1979.-1980.)

\section{Sažetak}

U radu se donose nova razmišljanja o okolnostima izgradnje crkve sv. Martina u Svetom Lovreču Pazenatičkom, odnosno iznose se neke nove pretpostavke o njezinoj izvornoj namjeni i njezinom naručitelju, a povezano s time preispituju se i dosadašnje spoznaje o povijesti samoga grada.

Naime, velika trobrodna bazilika sv. Martina smatra se jednim od najznačajnijih i najintrigantnijih istarskih srednjovjekovnih spomenika te jednom od najznačajnijih ranoromaničkih građevina na tlu čitave Hrvatske. Prema tipološkim i morfološkim obilježjima arhitekture i karakteristikama arhitektonske plastike te prema stilskim obilježjima prilično dobro sačuvanoga izvornog zidnog oslika, građevina je datirana u drugu trećinu 11. sto- 
ljeća, a njezina monumentalnost govori o tome da ju je morao izgraditi vrlo značajan istarski feudalac onoga vremena. Smještaj bazilike uz (danas nepostojeću) gradsku palaču te izravna komunikacija koja je postojala između dvije građevine upućuju na zaključak da naručitelja treba tražiti u upravitelju srednjovjekovnoga lovrečkog kastruma.

Pitanja o mogućem naručitelju crkve nalažu, prije svega, preispitivanje dosadašnjih spoznaja o povijesti samoga grada. Na temelju ponovnog iščitavanja te ponešto promijenjene interpretacije nekih od već poznatih povijesnih dokumenata, relativizira se općeprihvaćena teza da je kastrum u doba izgradnje crkve i u narednim razdobljima bio u feudu porečkoga biskupa - u spomenutim se dokumentima, naime, ne može naći izravna potvrda za takvu tvrdnju. Naposljetku, navode se neki dosad zanemareni, a relevantni povijesni podaci, koji otvaraju prostor za daljnja promišljanja, osnažujući pretpostavku da je crkvu dao izgraditi neki drugi pripadnik lokalne feudalne elite, moguće sam istarski grof ili markgrof, upravo u razdoblju tijekom kojega je, smatra se, Istra dobila status samostalne markgrofovije.

\section{La chiesa di S. Martino a San Lorenzo del Pasenatico - chiesa privata dei vescovi parentini o dei conti/margravi istriani?}

\section{Nikolina Maraković}

\section{Riassunto}

L'articolo presenta nuove considerazioni sulle circostanze della costruzione della chiesa di S. Martino di San Lorenzo del Pasenatico, ossia espone alcune nuove presupposizioni sulla sua finalità primaria e sul committente, il che porta alla revisione dei fatti di storia finora conosciuti riferiti alla città stessa.

Infatti, la grande basilica a tre navate di S. Martino, è considerata uno dei monumenti medievali istriani più significativi ed intriganti ed una tra le costruzioni più rilevanti del primo romanico in tutto il territorio della Croazia. Secondo le caratteristiche tipologiche e morfologiche dell'architettura, gli aspetti della plastica architettonica e le proprietà stilistiche dell'affresco originale ben conservato, l'edificio è datato nel secondo terzo del XI secolo e la sua monumentalità testimonia il fatto che è dovuta essere commissionata da un importante feudatario istriano del tempo. L'ubicazione della basilica accanto al palazzo comunale (oggi non più esistente) e l'esistenza della comunicazione diretta tra i due edifici portano alla conclusione che il committente avrebbe potuto essere stato il procuratore del castro di San Lorenzo.

Le questioni sull'identità del probabile commissionario della chiesa, impongono innanzitutto un riesame delle conoscenze finora acquisite sulla città stessa. In base ad una rilettura e ad un'interpretazione moderatamente modificata di alcuni documenti storici già conosciuti, viene relativizzata la tesi generalmente accettata che al momento della costruzione della chiesa il castro appartenesse al feudo del vescovo parentino - nei documenti menzionati, infatti, non è riscontrabile una conferma diretta di tale affermazione. Infine, vengono menzionati alcuni dati storici trascurati che offrono lo spazio per ulteriori riflessioni, consolidando il presupposto che la chiesa avrebbe potuto essere stata eretta da qualche altro rappresentante dell'elite locale, forse lo stesso conte o margravio istriano, proprio nel periodo in cui si ritiene l'Istria abbia acquisito lo status di margraviato. 


\section{The Church of St. Martin in Sveti Lovreč Pazenatički - a private church of Bishops of Poreč or Istrian counts/margraves? \\ Nikolina Maraković}

\section{Summary}

The article deals with the church of St. Martin in Sveti Lovreč Pazenatički, questioning in the first place the historical context of its foundation, presenting some new assumptions about its original dedication and function, and consequently, questioning the accepted ideas about the history of the town.

The large three aisled basilica of St. Martin belongs to the most significant and intriguing Istrian medieval monuments and is one of the most exceptional early Romanesque buildings in Croatia. According to the typological and morphological features of the architecture, as well as the stylistic traits of rather well preserved original mural paintings, the church has been dated to the second third of the eleventh century. Its monumentality tells us that it must have been built by one of the most important members of Istrian feudal society of the time. The placement of the church by the (no more existent) town palace and the direct communication which existed between the two buildings lead to the conclusion that the church must have been built by the chief administrative officer of the medieval castrum Sveti Lovreč.

The questions about the possible patron of the church require, in the first place, reexamination of the existing ideas considering the history of the town. The formerly accepted thesis that, at the time of the building of the church and in the following periods, the castrum belonged to the bishop of Poreč, is put into question by reexamination, and a somewhat changed interpretation, of some of the well-known historical documents - the mentioned documents, in fact, provide no direct confirmation for such a thesis. Finally, some of the previously neglected but, in our opinion, relevant historical data are referred to, as they provide ground for a reconsideration of the former hypotheses. They can be used to support an assumption that the church was built by some other member of local feudal elite, possibly the Istrian count or margrave himself, in the period when Istria, as it is supposed, was elevated to the status of an autonomous march. 